\title{
KETERIKATAN KARYAWAN DAN KONTRIBUSINYA DALAM MENINGKATKAN KINERJA PERUSAHAAN
}

\author{
Rusdin Tahir \\ Program Studi IImu Administrasi Bisnis, Fakultas IImu Sosisal dan IImu Politik \\ Universitas Padjadjaran.Email: rusdin.tahir@yahoo.com
}

\begin{abstract}
Abstrak
Salah satu unsur penting dalam kinerja operasional BUMN adalah Peningkatan Kualitas Perencanaan, SDM, dan Pengelolaan Keuangan yang dapat berperan sebagai alat pengawasan sekaligus performance driver. Karenanya, melalui penelitian ini telah ditelaah sejauhmana kontribusi keterikatan karyawan, seperti keterikatan kognisi, keterikatan emosional, dan keterikatan perilaku dapat memberikan kontribusi dalam meningkatkan kinerja BUMN di Indonesia. Penelitian ini dilakukan dengan metode survei terhadap 429 orang Manajer Madya pada 141 perusahaan BUMN di Indonesia. Teknik pengumpulan data dilakukan dengan teknik komunikasi tidak langsung melalui instrumen berupa angket dan teknik komunikasi langsung melalui wawancara terbatas dan studi dokumentasi. Penelitian ini dilakukan dari Bulan Januari 2011 yang berakhir 31 Desember 2012. Teknik pengolahan data dilakukan dengan Analisis Deskriptif, yaitu rata-rata terbobot, dan Analisis inferensial yaitu Structural Equation Modeling (SEM). Hasil penelitian menunjukkan bahwa: Keterikatan karyawan pada BUMN di Indonesia menunjukkan kondisi yang baik, namun belum optimal. Demikian halnya kinerja perusahaan berbasis total performance scorecard. Keterikatan karyawan meliputi keterikatan kognisi, emosional, dan perilaku secara parsial dan simultan berkontribusi positif dan bermakna dalam meningkatkan kinerja perusahaan berbasis total performance scorecard.
\end{abstract}

Kata Kunci: kinerja perusahaan, keterikatan karyawan, keterikatan kognisi, keterikatan emosional, keterikatan perilaku

\begin{abstract}
One of the important elements in the operational performance of SOEs is Improving the Quality Planning, Human Resources and Financial Management that can act as a surveillance tool as well as performance drivers. Therefore, through this research has explored the extent of contribution of engagement, such as attachment cognition, emotional attachment, and attachment behaviors can contribute in improving the performance of state-owned enterprises in Indonesia. This research was conducted by a survey of 429 people Associate Manager at 141 state-owned enterprises in Indonesia. Data was collected by indirect communication techniques through instruments such as questionnaires and interview techniques through limited direct communication and documentation study. The study was conducted from January 2011, which ended December 31, 2012. The data processing techniques with descriptive analysis, the weighted average and inferential analysis of the Structural Equation Modeling (SEM). The results showed that: the attachment of employees at state-owned enterprises in Indonesia showed a good condition, but not optimal. Similarly, the total performance-based corporate performance scorecard. Employee engagement include attachment cognition, emotional, and behavioral partially and simultaneously have a positive and significant effect on total performancebased corporate performance scorecard.
\end{abstract}

Keywords: firm performance, employee engagement, cognition engage, emotional engage, behavior engage 


\section{PENDAHULUAN}

Manajer SDM sering mengalami kesulitan terkait dengan berbagai kepentingan (seperti kepentingan antara agent dan principal). Manajer SDM mengalami kesulitan karena tingginya tuntutan dari karyawan yang memiliki Talenta. Perusahaan makin tanggap terhadap kebutuhan karyawan, karena tidak ingin kehilangan orang-orang terbaiknya. Kendati demikian, isu bajak membajak karyawan masih sering terdengar. Gejalanya adalah perusahaan yang ingin melesat/unggul, umumnya memilih membeli orang-orang terbaik dari luar organisasi, kendati harus mengeluarkan biaya yang mahal. Idealnya hal ini berisiko menimbulkan suasana yang kurang kondusif bagi perkembangan karier karyawan yang sudah mengabdi selama puluhan tahun di perusahaan tersebut.

Kehadiran generasi baru di lingkungan kerja yang sama sekali berbeda dengan orang-orang sebelumnya atau biasa disebut Gen Y. Paradigma praktisi Human Capital (HC) pun harus berubah. Praktisi HC harus siap menerima generasi baru yang memiliki perilaku dan gaya bekerja yang berbeda dengan generasi sebelumnya. Gejala yang ada pada umumnya praktisi HC belum mampu bahkan tidak dapat merespons situasi ini dengan baik, yang muncul adalah suasana yang tidak kondusif. Idealnya karyawan dari generasi sebelumnya diarahkan untuk menjadi mentor bagi karyawan dari Generasi Y.

Kondisi tersebut tidak kondusif, mengingat implementasi Undang-undang No 13/2003 masih dipertanyakan, bahkan saat ini masih direvisi dan sudah masuk Program Legislasi Nasional (Prolegnas), tapi tidak dibahas-bahas. Jadi efek sampingnya sangat besar. Investor tidak bisa masuk, sedangkan pengusaha lebih memilih tenaga outsource daripada merekrut karyawan permanen. Banyak pegawai yang memiliki kualifikasi pendidikan yang memadai, namun terbentur dengan posisi yang tidak sesuai dengan bidang pekerjaannya, pengikutsertaan pegawai/karyawan dalam pelatihan masih menerapkan sistem senioritas. Belum seimbangnya antara kualitas dan kuantitas sebagai akibat dari overstaffing dan pola recruitment yang kurang baik, rendahnya tingkat efektivitas system career path planning dan reward and funishment.

Permasalahan lain yang dihadapi BUMN (Forum Human Capital Indonesia, 2007), yaitu: (1) Guna mencapai keseimbangan nilai individu seperti dalam hal perbaikan yang berkesinambungan, misi pribadi, dan peran kunci pribadi belum banyak dilakukan; (2) Guna mencapai keseimbangan nilai organisasi, seperti: upaya perbaikan dan pengendalian proses bisnis yang berkesinambungan, pengembangan strategi, dan fokus pada pencapaian daya saing bagi perusahaan, belum banyak dilakukan; (3) Manajemen kualitas yang terintegrasi,seperti: upaya perbaikan proses produksi yang berkesinambungan, mengeliminir pemborosan, perbaikan kualitas, pengembangan keterampilan, dan efisiensi biaya produksi belum banyak dilakukan; (4) Manajemen kompetensi, seperti: upaya dalam proses pengembangan potensi, dan potensi karyawan yang berkesinambungan, belum banyak dilakukan; (5) Proses perputaran, seperti: pembenahan terhadap proses bisnis, keterampilan, dan perilaku pribadi karyawan (individu) berdasarkan pembelajaran, belum banyak dilakukan.

Gejala KK pada BUMN, terungkap dari hasil penelitian Syahnaz (2011) tentang peningkatan keunggulan daya saing, PT. PLN (Persero) Distribusi Jawa Timur yang dimulai dengan mengacu kepada Malcolm Baldrige Criteria for Performance Excellence (MBCFPE) yang telah dijadikan acuan bagi hampir semua BUMN di Indonesia, dengan melakukan Employee Engagement Survey (EES). EES merupakan sebuah survei pengukuran loyalitas karyawan terhadap KK.

Hasil penelitian tersebut, menunjukkan bahwa kriteria pada EES yang dikeluarkan oleh 
PT. PLN Kantor Pusat kurang dapat menggambarkan tingkat kepuasan kerja dan loyalitas karyawan yang sesuai dengan kondisi internal PT. PLN (Syahnaz, 2011).

TPS merupakan salah satu pendekatan yang sistematis dalam peroses menilai kinerja melalui perbaikan, pengembangan, dan pembelajaran yang berkesinambungan, melalui tahapan, dan rutin, yang terpusat kepada perbaikan kinerja pribadi dan organisasi secara berkelanjutan. Perbaikan, pembelajaran, dan pengembangan merupakan tiga kekuatan mendasar dalam konsep manajemen terpadu. Ketiganya terkait erat dan harus dijaga kesinambungannya (Rampersad, 2008:9-11). Hal ini cukup beralasan, karena manajemen setiap organisasi menyadari bahwa perbaikan, pengembangan, dan pembelajaran diperlakukan sebagai proses etis bersiklus dimana pengembangan kemampuan pribadi dan organisasi serta keterlibatan batin harus saling mengikat.

Merujuk pada kondisi yang telah diuraikan di atas, maka masih belum jelas benar, keterkaitan antara keterikatan karyawan (employee engagement) dengan kinerja berbasis total performance scorecard BUMN di Indonesia. Melalui penelitian ingin mengungkap sejauhmana kejelasan kontribusi employee engagement meliputi keterikatan kognisi, emosi, dan perilaku dalam meningkatkan kinerja BUMN di Indonesia berbasis total performance scorecard.

\section{KAJIAN PUSTAKA}

Kualitas kehidupan kerja berkaitan dengan komitmen terhadap pekerjaan dan organisasi, kebanggaan dalam pekerjaan dan dalam organisasi, kesediaan untuk mendukung manfaat dan keuntungan dari pekerjaan dan organisasi, dan kepuasan dengan pekerjaan dan organisasi, baik emosional maupun intelektual. Keempat hal tersebut terdapat pada employee engagement yang ditunjukkan oleh hasil penelitian Haid dan
Sims (2012), yang mengidentifikasi employee engagement dengan menggunakan empat faktor definitif: (1) Komitmen terhadap pekerjaan dan organisasi; (2) Kebanggaan dalam pekerjaan dan dalam organisasi; (3) Kesediaan untuk mendukung manfaat dan keuntungan dari pekerjaan dan organisasi; dan (4) Kepuasan dengan pekerjaan dan organisasi.

Hasil penelitian Ross, et al., (2006) yang dilakukaan terhadap 475 eksekutif dari perusahaan listrik di kawasan perdagangan bebas Malaysia, yang mengungkapkan kepuasan karir, pencapaian karir dan keseimbangan karir berpengaruh secara signifikan terhadap kualitas kehidupan kerja. Ketiga faktor tersebut diperkuat oleh hasil penelitian Sardar, et al (2010) yang mengungkapkan hubungan yang signifikan antara employee engagement dan pembuatan keputusan dan aspek-aspek lainnya dalam praktik MSDM yang diteliti.

Hasil penelitian Dollard dan Bakker (2010) menunjukkan bahwa (1) keterikatan karyawan dengan memimpin perusahaan memberikan pengaruh terhadap kepuasan pelanggan yang akhirnya mengarahkan organisasi terhadap hasil profitabilitas atau bisnis, dan (2) terdapat hubungan yang kuat antara keterikatan karyawan dengan kinerja perusahaan dan produk akhir, meskipun ditemukan bahwa organisasi yang berbeda mendefinisikan keterikatan yang berbeda, tetapi ada beberapa kesamaan dalam paraktik.

Berdasarkan hasil penelitian Ross, et al (2006), Sardar, et al (2010), dan Haid dan Sims (2012), menunjukkan bahwa karateristik yang terdapat pada keterikatan karyawan digambarkan pula oleh karakteristik yang terdapat pada kualitas kehidupan kerja. Dalam hasil studi lain ditunjukkann bahwa perilaku kewargaan organisasi berpengaruh terhadap keterikatan karyawan, hal ini ditunjukkan oleh hasil penelitian Ehigie dan Otukoya (2005), berkesimpulan bahwa untuk meningkatkan perilaku kewargaan organisasional antara 
karyawan dengan organisasi, terutama perusahaan milik pemerintah di Nigeria, manajemen perlu menetapkan perangkat kebijakan di tempat kerja yang akan menjamin peningkatan dukungan organisasi dan perlakuan yang adil terhadap semua orang dari tiga aspek perilaku kewargaan organisasi, yaitu membantu, kebajikan sipil, dan sportivitas mengarah pada peningkatan kinerja perusahaan milik pemerintah di Nigeria.

Hal tersebut sejalan dengan faktor penggerak keterikatan karyawan (McBain, 2007), yaitu: (1) Organisasi, hal terkait organisasi yang dapat menjadi penggerak keterikatan karyawan adalah budaya organisasi, visi dan nilai yang dianut, dan brand organisasi. Keadilan dan kepercayaan sebagai nilai organisasi juga memberikan dampak positif bagi terciptanya keterikatan karyawan. Hal tersebut akan memberikan persepsi bagi karyawan bahwa mereka mendapat dukungan dari organisasi; (2) Manajemen dan Kepemimpinan, keterikatan dibangun melalui proses, butuh waktu yang panjang serta komitmen yang tinggi dari pemimpin. Untuk itu, dibutuhkan konsistensi pemimpin dalam mementoring karyawan dalam menciptakan keterikatan karyawan, pemimpin organisasi diharapkan memiliki beberapa keterampilan, seperti teknik berkomunikasi, teknik memberikan feedback dan teknik penilaian kinerja (McBain, 2007); (3) Working life, kenyamanan kondisi lingkungan kerja menjadi pemicu terciptanya keterikatan karyawan.

Dengan demikian, upaya memberikan peluang kepada karyawan untuk berpartisipasi tidak terlepas dari: peran organisasi, kepemimpinan, dan kondisi lingkungan pekerjaan. Dalam kaitan ini ketiga faktor tersebut menjadi pendorong terjadinya keterikatan karyawan.

Hasil penelitian Saks (2006) menunjukkan, 6 faktor yang mempengaruhi keterikatan karyawan dengan perusahaannya, yaitu: (1) komunikasi dalam perusahaan, (2) kondisi kerja, (3) evaluasi dan pengembangan SDM, (4) ketentuan perusahaan, (5) reward dan remunerasi serta layanan SDM dari perusahaan. Dikaitkan dengan konstruksi dan indikator keterikatan karyawan yang telah dijelaskan sebelumnya, survei di berbagai negara menunjukan perbedaan faktor yang mempengaruhi keterikatan karyawan.

Penelitian James, McKechnie, dan Swanberg (2011) pada perusahaan jasa profesional, Grup Hay menemukan bahwa keterikatan kantor (perusahaan) dengan karyawan, menggerakkan karyawan menjadi 43\% lebih produktif. Lonjakan hampir 52\% pendapatan operasi perusahaan menurun diakibatkan oleh rendahnya keterikatan perusahaan dengan karyawan.

Keseluruhan karakteristik yang terdapat pada employee engagement terkait dengan upaya yang dilakukan organisasi bisnis (perusahaan) pada umumnya dalam ningkatkan kinerja karyawan dan organisasi (Robbins dan Judge, 2013). Kinerja perusahaan berbasis TPS merupakan proses penemuan yang berkesinambungan melibatkan perbaikan, pengembangan, dan pembelajaran, yang: focus pada pelanggan, focus pada tujuan pribadi dan organisasi, Hasrat dan Kenikmatan, Etika dan Perilaku, Orientasi Proses, Fokus pada Perbaikan, dan Pengembangan, \& Pembelajaran (Rampersad, 2008).

Keseluruhan karakteristik yang terdapat pada kinerja berbasis total performance scorecard, sejalan dengan hasil penelitian Haid dan Sims (2012:7), yang mengidentifikasi employee engagement sebagai performance driver, karena employee engagement memiliki karakteristik, karyawan memiliki: (1) Komitmen terhadap pekerjaan dan organisasi;(2) Kebanggaan dalam pekerjaan dan dalam organisasi; (3) Kesediaan untuk mendukung manfaat dan keuntungan dari pekerjaan dan organisasi; dan (4) Kepuasan dengan pekerjaan dan organisasi.

3. METODE PENELITIAN 
Penelitian ini menggunakan Metode Survei Penjelasan (Explanatory Survei Method). Walaupun uraiannya juga mengandung deskripsi, tetapi sebagai penelitian relasional fokusnya terletak pada penjelasan hubungan antar variabel. Penelitian ini mengungkap mengenai tingkat keberlakuan umum atau generalisasi dari hasilnya, dibatasi pada fenomena yang terjadi dilokasi penelitian. Variabel Keterikatan Karyawan/KK (Employee Engagement), diukur melalui indikator-indikator yang merupakan ciri dari variabel ini, yang dioperasionalkan menjadi 10 pernyataan, dengan menggunakan instrumen berupa kuesioner. Variabel Kinerja Perusahaan dengan pendekatan Total Performance Scorecard (TPS), diukur melalui indikator-indikator yang merupakan ciri dari variabel ini, yang dioperasionalkan menjadi 54 pernyataan, dengan menggunakan instrumen berupa kuesioner. Hasil dari kuesioner ini merupakan data yang berskala ordinal, dengan skor berkisar 1- 5 setiap itemnya.

Unit populasi dalam penelitian ini 141 BUMN, sedangkan unit observasinya 36.619 orang manajer madya yang bekerja pada BUMN. Dengan menggunakan teknik penarikan sampel secara random sederhana, ditetapkan ukuran sampel 429 Orang Manajer Madya di Seluruh BUMN di Indonesia. Berdasarkan tujuan penelitian ini, maka Manajer Madya, dinilai refresentatif mewakili seluruh BUMN di Indonesia, karena Manajer Madya (Middle Manager) merupakan pembuat/pengambil keputusan di level 1 dan/atau level 2 di bawah level Direksi (Top Manager) dan di atas level Manajer Pelaksana (Lower Manager). Manajer Madya bertindak sebagai pemimpin untuk memberikan persepsi tentang tentang keterikatan karyawan (employee engagement) dan kinerja berbasis Total Performance Scorecard pada BUMN di Indonesia.

Teknik pengumpulan data dilakukan dengan Teknik Komunikasi Tidak Langsung dan Teknik Komunikasi Langsung. Teknik Komunikasi Tidak langsung menggunakan Kuesioner sebagai instrumen. Sedangkan Teknik Komunikasi Langsung menggunakan wawancara terbatas dan studi dokumentasi sebagai instrumen.

Penelitian ini menggunakan analisis deskripif (Weighted Means Score) dan inferensial/verifikasi (Structural Equation Modeling (SEM), dengan alasan bahwa analisis ini merupakan pendekatan terintegrasi antara Confirmatory Factor Analysis, Structural Model, dan Path Analysis.

\section{HASIL DAN PEMBAHASAN}

Jumlah BUMN terkait kepemilikan Pemerintah secara langsung dan berada di bawah kementerian BUMN, terdapat 141 BUMN yang terdiri dari 14 BUMN berbentuk Perum, 109 BUMN berbentuk Persero, dan 18 BUMN yang merupakan Persero Terbuka. Selain itu, Negara juga mempunyai kepemilikan saham minoritas pada 15 badan usaha. Namun penelitian ini hanya meneiliti 141 BUMN (saham mayoritas).

Keterikatan Karyawan dipersepsi oleh Manajer Madya pada BUMN secara keseluruhan, mencapai rata-rata $61,23 \%$ dari skor idealnya. Nilai tersebut termasuk kategori tinggi. Artinya Keterikatan Karyawan pada BUMN sudah baik. Hal tersebut ditelusuri dari 3 (tiga) variabel manifes, pengetahuan dan pemahaman (kognitif), emosional, dan perilaku.

Tabel 1

Tanggapan Manajer Madya Terhadap Keterikatan Karyawan (KK)

\begin{tabular}{lcccc}
\hline $\begin{array}{l}\text { Variabel } \\
\text { Manifes }\end{array}$ & $\begin{array}{c}\text { Actual } \\
\text { Score }\end{array}$ & $\begin{array}{c}\text { Ideal } \\
\text { Score }\end{array}$ & (\%) & Ket \\
\hline $\begin{array}{l}\text { Keterikatan } \\
\text { Kognitif }\end{array}$ & 4.035 & 6,435 & 62.70 & Tinggi \\
\hline $\begin{array}{l}\text { Keterikatan } \\
\text { Emosi }\end{array}$ & 6.365 & 10,725 & 59.35 & Cukup \\
\hline Keterikatan & 4.048 & 6,435 & 62.91 & Tinggi \\
\hline
\end{tabular}




\begin{tabular}{rrrrr}
\hline \multicolumn{1}{l}{ Perilaku } & & & & \\
\hline TOTAL & 15.693 & 23.595 & 61,23 & Tinggi \\
\hline
\end{tabular}

Sumber: Data Primer, diolah penulis, 2012

Dengan kata lain, keterikatan karyawan pada BUMN ditunjukkan oleh persepsi Manajer Madya yang belum optimal. Hal tersebut dinilai cukup beralasan karena masih terdapat beberapa indikator yang termasuk kategori cukup, seperti: pada dimensi kognitif (KK1) terutama indikator pengetahuan dan pemahaman karyawan terhadap pemimpin mereka $\left(\mathrm{Y}_{2}\right)$ dan dimensi emosional (KK2) terutama pada indikator komitmen karyawan terhadap lingkungan kerja mereka, bahkan terdapat indikator yang dinilai rendah, seperti: sikap positif manajer madya terhadap organisasi dan pemimpin mereka ( $\left.Y_{7 . b}\right)$ pada dimensi emosional (KK2), dan indikator ketertarikatannya dengan pekerjaan yang dihadapi $\left(Y_{8}\right)$ pada dimensi perilaku (KK3).

Model dalam penelitian ini, dikaji dari fenomena di lapangan, dengan menggunakan variabel yang digali dari permasalahan di lapangan. Model yang terbentuk didasarkan pada teori-teori parsial antar model, sehingga dari beberapa teori pendukung tersebut diperoleh suatu bentuk model.

\section{Uji Goodness of fit Statistics}

Hasil ketepatan model yang diperoleh (pengujian model secara simultan atau keseluruhan) ditunjukkan oleh ukuran kesesuaian model (Goodness of fitstatistics) dapat diringkaskan seperti terlihat pada Tabel 2 sebagai berikut:

\section{TABEL 2}

\section{EVALUASI KRITERIA GOODNESS OF FIT INDICES}

\begin{tabular}{lrrr}
\hline Kriteria & Hasil & Nilai Kritis & $\begin{array}{c}\text { Evaluasi } \\
\text { Model }\end{array}$ \\
\hline $\begin{array}{l}\chi^{2}(\mathrm{CMIN}) \\
\mathrm{Df}=5350\end{array}$ & 3998,169 & $\begin{array}{r}\text { Diharapkan } \\
\text { kecil }\end{array}$ & Marginal \\
\hline $\begin{array}{l}\text { Significance } \\
\text { Probability }\end{array}$ & 0,0000 & $\geq 0,05$ & Marginal \\
\hline CMIN/DF & 1,124 & $\leq 2,00$ & Baik \\
\hline
\end{tabular}

\begin{tabular}{lccl}
\hline RMSEA & 0.0640 & $\leq 0,08$ & Baik \\
\hline $\begin{array}{l}\text { Goodness of } \\
\text { Fit Index (GFI) }\end{array}$ & 0,89 & $\geq 0,90$ & Marginal \\
\hline $\begin{array}{l}\text { Normed Fit } \\
\text { Index (NFI) }\end{array}$ & 0,97 & $\geq 0,90$ & Baik \\
\hline
\end{tabular}

Sumber : Data primer diolah, 2013

Hasil pengujian model dengan memperhatikan nilai $\chi^{2}$, maka diperoleh nilai $\chi^{2}$ besar $(p=.000 ; \alpha=0,05)$. Tetapi karena rasio CMIN dengan DF masih kurang dari 2, maka dapat dinyatakan model struktural yang terbentuk dapat diterima (fit dengan data). Ukuran Goodness of Fit Statistics yang lainnya juga menunjukkan model masih dapat digunakan dimana RMSEA untuk model struktural 0,064 lebih kecil dari nilai kritis 0,8 dan Normed Fit Index (NFI) model 0,97 lebih besar dari nilai kritis $(0,90)$. Nilai GFI model masuk dalam kriteria marginal.

Berdasarkan ukuran kecocokan model yang diperoleh dapat disimpulkan bahwa model struktural yang terbentuk sesuai dengan data dan dapat dikatakan memenuhi kriteri Goodness of Fit.

Hasil pengujian pengaruh variabel eksogen Employee Engagement terhadap variabel endogen Total Performance Scorecard, menunjukkan: (1) Total Performance Scorecard pada BUMN di Indonesia terbukti secara nyata dipengaruhi oleh Employee Engagement kualitas secara simultan dengan koefisien determinasi sebesar 0,622 atau 62,2\% ( $p=.000 ; \alpha=.05)$; (2) Total Performance Scorecard pada BUMN di Indonesia terbukti secara nyata dipengaruhi oleh Cognitive Engagement secara parsial dengan koefisien determinasi sebesar 0,78 atau $7,8 \%$ ( $p=.000 ; \alpha=.05$ ); (3) Total Performance Scorecard pada BUMN di Indonesia terbukti secara nyata dipengaruhi oleh Emosional Engagement secara parsial dengan koefisien determinasi sebesar 0,210 atau $21 \% \quad(p=.000 ; \alpha=.05)$; (4) Total Performance Scorecard pada BUMN di Indonesia terbukti secara nyata dipengaruhi oleh Behavior Engagement secara parsial dengan koefisien 
determinasi sebesar 0,334 atau 33,4\% ( $p=.000$; $\alpha=$.05).

Dengan demikian hipotesis yang menyatakan bahwa Keterikatan karyawan berkontribusi dalam meningkatkan Kinerja Perusahaan berbasis Total Performance Scorecard Pada BUMN di Indonesia dapat diterima. Dengan kata lain Kinerja Perusahaan berbasis Total Performance Scorecard pada BUMN di Indonesia turut ditentukan oleh keterikatan karyawan (employee engament). Model persamaan statistik, sebagai berikut:

\section{$K K=.279 K K 1+.459 K K 2+.578 K K 3+.378$}

Hasil penelitian ini sejalan dengan hasil penelitian Haid dan Sims (2012) yang menyimpulkan bahwa kualitas kehidupan kerja akan meningkatkan: (1) komitmen karyawan terhadap pekerjaan dan organisasinya, (2) karyawan merasa bangga dalam melakukan pekerjaan dan bangga berada dalam organisasi, (3) karyawan akan bersedia untuk mendukung peningkatan manfaat dan keuntungan dari pekerjaan dan organisasi, dan (4) karyawan akan merasa puas dengan pekerjaan dan organisasi, baik emosional maupun intelektual. Ke empat hal tersebut terdapat merupakan karakteristik dari keterikatan karyawan dan menjadi performance driver.

Dengan kata lain, hasil penelitian ini sejalan dengan hasil penelitian sebelumnya. Meskipun demikian, hasil penelitian ini menunjukkan belum optimalnya keterikatan karyawan yang dirasakan Manajer Madya selaku manajer, yang ditunjukkan oleh indikator: Pengetahuan dan pemahaman karyawan terhadap pemimpin mereka, yang hanya mencapai 51,89\% dari skor idealnya, Komitmen karyawan terhadap lingkungan kerja mereka, yang hanya mencapai $50,40 \%$ dari skor idealnya, tingginya sikap negatif $(60,37 \%)$ dan rendahnya sikap positif $(38,83 \%)$ mereka terhadap organisasi dan pemimpin mereka, dan rendahnya $(38,04 \%)$ ketertarikan manajer atas pekerjaan yang dihadapi. Masih ada faktor lain $(44,79 \%)$ yang berpengaruh terhadap Total performance scorecard pada BUMN di Indonesia, selain keterikatan karyawan yang diduga, di antaranya, belum adanya keseragaman (standar) Kebijakan Remunerasi, dalam analisis annual report (2011) BUMN ditemukan masih terdapat BUMN yang serumpun pun, tetapi tidak memiliki cara analisis jabatan dan rumusan sistem remunerasi yang sama. Pemberian remunerasi (kompenasi) baik yang bersifat finansial maupun non finansial belum ada keseragaman, sehingga memberikan peluang kepada karyawan untuk memilih perusahaan di luar yang menawarkan lebih tinggi.

Secara khusus hasil penelitian ini juga sejalan dengan teori perilaku organisasi dari Robbins dan Judge (2013) yang menyatakan keterikatan karyawan (employee engagemant) sesungguhnya tumbuh karena diciptakan dan dikembangkan oleh individu-individu yang bekerja dalam suatu organisasi, dan diterima sebagai nilai-nilai yang dipertahankan dan diturunkan kepada setiap anggota baru, yang akan mempengaruhi kinerja mereka dan organisasi tempat mereka bekerja.

\section{PENUTUP}

\subsection{Kesimpulan}

1. Keterikatan karyawan pada BUMN di Indonesia menunjukkan kondisi yang baik, namun belum optimal. Belum optimalnya keterikatan karyawan yang dirasakan Manajer Madya selaku manajer, yang ditunjukkan oleh indikator: Pengetahuan dan pemahaman karyawan terhadap pemimpin mereka, yang hanya mencapai $51,89 \%$ dari skor idealnya, Komitmen 
karyawan terhadap lingkungan kerja mereka, yang hanya mencapai 50,40\% dari skor idealnya, tingginya sikap negatif $(60,37 \%)$ dan rendahnya sikap positif $(38,83 \%)$ mereka terhadap organisasi dan pemimpin mereka, dan rendahnya (38,04\%) ketertarikan manajer atas pekerjaan yang dihadapi.

2. Kondisi Kinerja perusahaan berbasis total performance scorecard pada BUMN di Indonesia sudah baik, namun belum optimal. Hal tersebut dinilai cukup beralasan karena masih terdapat beberapa indikator yang termasuk kategori sedang, seperti: (a) Organisasi peduli dengan etika dan tanggungjawab sosial perusahaan, dan (b) Seluruh karyawan terbuka terhadap perubahan, perbaikan, dan pembaruan. Terdapat indikator yang dinilai rendah, seperti: (a) Intervensi pada SDM (khususnya pelatihan) diutamakan, (b) karyawan diberdayakan, (c) Membuat kesalahan diperbolehkan, karena karyawan selalu belajar dari kesalahan, (d) Karyawan memperbaiki diri sendiri dan pekerjaannya, dan (e) membantu karyawan lain untuk memperbaiki diri sendiri \& organisasi, dan (f) Kebutuhan pelanggan menyatu dalam kegiatan karyawan sehari-hari.

3. Keterikatan Karyawan secara nyata berkontribusi dalam meningkatkan kinerja perusahaan pada BUMN di Indonesia. Hal ini dapat ditelusuri dengan mengamati keterikatan kognisi, emosional, dan perilaku manajer selaku karyawan baik secara parsial maupun secara simultan berpengaruh secara nyata terhadap kinerja berbasis total performance scorecard pada BUMN di Indonesia.

\subsection{Rekomendasi}

Konstruk Keterikatan karyawan, masih terdapat indikator yang dinilai rendah, yakni sikap positif Manajer Madya terhadap organisasi dan pemimpin mereka pada dimensi keterikatan emosional, dan indikator ketertarikatannya dengan pekerjaan yang dihadapi pada dimensi keterikatan perilaku. Tim pemimpin/manajemen yang memiliki keterikatan yang kuat terhadap perusahaan, dan menerapkan kompetensi kepemimpinan yang efektif, merupakan unsur yang sangat esensial dalam keterikatan karyawan.

Kapabilitas kepemimpinan, yang dinilai sangat penting dalam keterikatan karyawan, yaitu: membangun kepercayaan, membangun rasa kepercayaan diri karyawan, berkomunikasi secara efektif, membangun lingkungan kerja yang menyenangkan dan pemenuhan pengetahuan, fleksibel dalam memahami kebutuhan individu, mengembangkan bakat dan melatih anggota tim, memacu tingkat kinerja yang berkualitas tinggi, menguasai pengetahuan yang diperlukan, mengawasi isu yang berkaitan dengan keterikatan karyawan.

Mengidentifikasi anggota tim, yang sesuai untuk tim kerja, karyawan akan tinggal bekerja lebih lama, dan memberikan kontribusi yang lebih besar kepada perusahaan, jika mereka memiliki hubungan yang baik, dan dialog terbuka dengan atasan langsung mereka. Hasil penelitian ini, menunnjukkan bahwa: kinerja BUMN berbasis total performance scorecard belum optimal, masih terdapat beberapa indikator yang termasuk kategori sedang, seperti: (1) Organisasi peduli dengan etika dan tanggungjawab social perusahaan, dan (2) Seluruh karyawan terbuka terhadap perubahan, perbaikan, dan pembaruan. Terdapat indikator yang dinilai rendah, seperti: (1) Intervensi pada SDM (khususnya pelatihan) diutamakan, (2) karyawan diberdayakan, (3) Membuat kesalahan diperbolehkan, karena karyawan selalu belajar dari kesalahan, (4) Karyawan memperbaiki diri sendiri dan pekerjaannya, dan (5) membantu karyawan lain untuk memperbaiki diri sendiri \& organisasi, dan (6) Kebutuhan pelanggan menyatu dalam kegiatan karyawan sehari-hari. Sementara dimensi yang paling tinggi persentasenya yakni dimensi fokus pada pelanggan. 
Kementerian BUMN, sebaiknya meninjau dan mengakji ulang terhadap Kepmen BUMN No. Kep-100/MBU/2002, tanggal 4 Juni 2002 tentang Penilaian Tingkat Kesehatan BUMN, yang masih berlaku sampai saat ini, dan memasukan indikator yang membangun kinerja perusahaan berbasis total performance scorecard yang tidak ditemukan dalam kepmen tersebut, dan mengitegrasikan prinsip Good Public Governance (GPG) dalam menjalankan fungsi regulasi dan penerapan Good Corporate Governance (GCG) dalam menjalankan fungsi korporasi, serta mewajibkannya bagi semua BUMN.

\section{DAFTAR PUSTAKA}

Aon Hewitt. 2012. Trends in Global Employee Engagement. Aon Hewit. http://www.aon.com/attachments/thoughtleadership/Trends Global_Employee

Engagement Final.pdf., $\quad$ [diakses 08/08/2012]

Barney, Jay B., William S. Hesterly. 2012. Strategic Management and Competitive Advantage: Concept and Cases. $4^{\text {th }}$ Edition. USA: Pearson.

Becker, Brian E, Mark A. Huselid, and Dave Urlich, 2009. The HR Scorecard: Linking People, Strategy, and Performance. USA: Harvard College.

Bernardin, H. John and Jouce E. A. Russel. 2013. Human Resource Management: An Experiential Approach. $6^{\text {th }}$ Edition. New York: McGraw-Hill.

Carton, Robert B., and Charles W. Hofer, 2006. Measuring Organizational Performance. USA: Edward Elgar Publishing Limited.

Dollard, Maureen and Arnold B Bakker. 2010. Psychosocial Safety Climate as a Precursor to Conducive Work Environments, Psychological Healt Problem, and Employee Engagement. Journal Occupational and Organizational Psychology. Vol. 83., Issue.3, p.579.
Ehigie Benjamin Osayawe and Olanrewaju Wahab Otukoya. 2005. Antecedents of organizational citizenship behaviour in a government-owned enterprise in Nigeria. European Journal of Work ond Organizational Psychology. Vol. 14 No.4., pp.389-399.

Feruniak, Geoffey S. 2008. The Promise of Quality of Life. Journal of Employment Counseling. June 2008. Vol. 45, pp.5075 .

Finney, Martha I., 2010. The Truth About Getting The Best From People. Engagement. Jakarta: PPM

Forum Human Capital Indonesia, 2007. Excellent People: Pemikiran Strategik mengenai Human Capital Indonesia. Jakarta: Gramedia.

Gallup, 2011. Employee Engagement. http://www.gallup.com/consulting/52/ employee-engagement.aspx

Ghosh, Samir and Subrata Mukherjee, 2006. Measurement of Corporate Performance Through Balanced Scorecard: an Overview. Vidyasagar University Journal of Commerce, 113.

Haid, Michael and Jamie Sims. 2012. Employee Engagement Maximizing Organizational Performance. Right Management. Business and Talent Organization.

http://www.aon.com/human-capitalconsulting/thoughtleadership/compensation/report global tre nds employee engagement.jsp., akses 05/05/2012

Kessler, Robin, 2011. Competency Based Performance Reviews: Evaluasi Kinerja Karyawan untuk mencapai sasaran strategi organisasi. Jakarta: PPM

Konrad, Alison M. 2006. Engaging Employees through High-Involvement Work Practices. Ivey Business Journal. http://web.ebscohost.com/ehost/pdf?vid= 54\&hid=120\&sid=5d29fefe-0913-49de- 
82b6-9b95ee1a4f09\%40sessionmgr 105. Retrieved 2006-11-14.

Kruse, Kevin. 2012. Employee Engagement: How to Motivate Your Team for High Performance (A Real-World Guide for Busy Managers). USA: The Kruse Group.

Maheshwari, V. 2008. Employee Engagement In Driving Business Performance. Proceeding dari Seminar Pembaruan Manajemen Bisnis Indonesia. Seminar Nasional Manajemen Bisnis Indonesia ke-2. Prasetiya Mulya Business School. Jakarta.

Makhijani, Naresh., Krishnan Rajendran., and James Creelman, 2009. Managing Human Capital in Indonesia: Best Practices in Aligning People With Strategic Goals. Azkia Publisher.

Markos, Solomon and M. Sandhlya Sridevi. 2010. Employee Engagement: The Key to Improving Performance. International Journal of Business and Management. December 2010; Vol.5, No.12.

McBain, Richard. 2007. The practice of engagement: Research into current employee engagement practice", Strategic HR Review, Vol. 6 Iss: 6, pp.16 - 19

Noe, Raymond A., John R. Hollenbeck, Barry Gerhant, and Patrick M. Wright. 2010. Human Resource Management. $7^{\text {th }}$ Edition. New York: McGraw-Hill.

Pemerintah RI., 2013. Undang-Undang Nomor 13 Tahun 2003 tentang Keternagakerjaan. http://www.hukumonline.com/pusatdata/d etail/13146/node/10/uu-no-13-tahun-2003ketenagakerjaan. [diakses 02/2/2013]

Rampersad, Hubert K., 2006. Personal Balanced Scorecard: The Way to Individual Happiness, Personal Integrity, Organizational Effectiveness. USA: Information Age Publishing (AGE). ., 2008. Total Performannce Scorecard: Redefining Management to Active Performance with Ingrety. Copy RightCetakan ke Dua. Jakarta: Gramedia.
Rashid,Hafiz Abdur, Ammar Asad, and Mian Muhammad Ashraf. 2011. Factors Persuading Employee Engagement and Linkage of EE to Personal \& Organizational Performance. Interdisciplinary Journal of Contemporary Research in Business. Vol. 3 No.5, pp. 98-108.

Robbins, Stephen P., and Timoty A. Judge., 2013. Organizational Behavior. 15 $5^{\text {th }}$ Edition. New Jersey : Prentice-Hall International Inc.

Robinson, Dilys and Sue Hay day. 2011. "Employee Engagement". In Brief (129). http://www. employment-studies.co.uk/ news/129theme.php. Retrieved 2011-11-06.

Rose, Raduan Che, LooSee Beh, Jegak Uli and Khairuddin Idris. 2006. An Analysis of Quality Work of Life and Caree-Related Variables. American Journal of Applied Science. Vol.3., No.12, pp.2151-2159.

Syahnaz, Andina. 2011. Selection of Improvement Job Satisfaction And Employee Loyalty Alternative for PT. PLN (Persero) Distribusi Jawa Timur With Topsis Approach. http://digilib.its.ac.id/ITSUndergraduate-3100010040707/14072, akses 30 Juli 2011.

Saks, A. M. 2006. Antecedents and Consequences of Employee Engagement. Journal Managerial Psychology, Vol. 21, No.7

Sardar, Saima., Adul Rechman, Usman Yousuaf, and Asad Yousaf. 2011. Impact of HR Practices on Employee Engagement in Banking Sector of Pakistan. Interdisciplinary Journal of Contemporary Research in Business. January, Vol.2 No.2, pp.378-389.

Scherrer, Pascal., Lynnaire Sheridan, Ruth Sibson, Maria M. Ryan, and Nadine Henly. 2011. Employee Engagement with A Corporate Physical Activity Program: The Global Corporate Challenge. International Journal of Business Studies. Vol. 18.No.1.,pp.125139. 
Urlich, Dave. 2008. Human Resource Champions: The Next Agenda for Adding Value and Delivering Results.

Vazirani, Nitin., 2011. Employee Engagement. Working Paper. Vol. 05. No.07. SIES College of Management Studies Neru.

Watson Wyatt Worldwide. 2011. Employee Commitment Remains Unchanged. http://www.watsonwyatt.com/research/res render.asp?id=W-557\&page $=6 . \quad$ Retrieved 2011-11-07.

Wellins, Richard S., Paul Bernthal, Mark Phelps. 2012. Employee Engagement: The Key to Realizing Competitive Advantage. Competitive Advantage Realized Journal. Development Dimensions International. Inc.

Wheelen, Thomas L., and J David Huner, 2012. Strategic Management and Business Policy, $13^{\text {th }}$ Edition. New Jersey: Printice Hall.

Wilson, Kevin. 2009. A Survey of Employee Engagement. A Dissertation. Faculty of the Raduate School. University of MissouriColumbia 